\title{
PENGARUH LITERASI KEUANGAN, PERENCANAAN KEUANGAN DAN PENDAPATAN TERHADAP KESEJAHTERAAN KEUANGAN GURU PEREMPUAN DI KOTA DENPASAR
}

\author{
Anisa Putri Nur Hidayah ${ }^{1}$ \\ Ida Bagus Anom Purbawangsa ${ }^{2}$ \\ Nyoman Abundanti ${ }^{3}$ \\ 1,2,3 Fakultas Ekonomi dan Bisnis Universitas Udayana (Unud), Bali, Indonesia \\ email: anisaputrinurhidayah@gmail.com
}

\begin{abstract}
ABSTRAK
Literasi keuangan merupakan pengetahuan dan kemampuan keuangan yang berpengaruh terhadap upaya dalam meningkatkan kesejahteraan keuangan. Penelitian mempunyai tujuan untuk memperoleh bukti empiris literasi keuangan, perencanaan keuangan dan pendapatan berpengaruh terhadap kesejahteraan keuangan. Data yang digunakan dalam penelitian berupa data primer yang dihimpun dengan melakukan survei berupa menyebarkan kuesioner dan wawancara pada guruguru perempuan di Kota Denpasar. Sampel ditentukan dengan teknik nonprobability sampling jenis quota sampling. Penelitian ini menggunakan teknik analisis data dengan software Partial Least Square (PLS). Penelitian ini menunjukkan hasil bahwa literasi keuangan, perencanaan keuangan dan pendapatan berpengaruh secara positif dan signifikan terhadap kesejahteraan keuangan pada guru-guru perempuan di Kota Denpasar. Implikasi dari hasil penelitian secara teoritis menambah referensi riset empiris tentang konsep literasi keuangan dan teori kesejahteraan. Hal ini menunjukkan bahwa literasi keuangan yang mencakup pengetahuan, keterampilan dan keyakinan individu dalam mengatur keuangannya akan memengaruhi keputusan keuangan yang akan dibuat untuk mencapai kesejahteraan keuangan yang diharapkan.

Kata kunci: Literasi Keuangan, Perencanaan, Pendapatan, Kesejahteraan.
\end{abstract}

\begin{abstract}
Financial literacy is financial knowledge and capability that affects efforts to improve financial well-being. This study aims to obtain empirical evidence that financial literacy, financial planning, and income have an effect on financial well-being. The data used in the research is primary data which was collected by conducting a survey in the form of distributing questionnaires and interviews with female teachers in Denpasar City. The sample is determined by the nonprobability sampling technique, quota sampling type. This study uses data analysis techniques Structural Equation Model (SEM) with Partial Least Square (PLS) software. This study shows that financial literacy, financial planning, and income have a positive and significant effect on the financial welfare of female teachers in Denpasar City. The implications of the theoretical research results add to the reference to empirical research on the concept of financial literacy and welfare theory. This shows that financial literacy which includes the knowledge, skills, and beliefs of individuals in managing their finances will influence financial decisions that will be made to achieve the expected financial well-being.
\end{abstract}

Keywords: Financial Literacy, Planning, Income, Welfare. 


\section{PENDAHULUAN}

Permasalahan terkait ketimpangan gender yang sudah menjadi bahasan di berbagai penelitian menunjukkan bahwa upaya untuk memberikan kesetaraan gender masih berlangsung hingga saat ini. Indonesia sendiri juga masih berkutat pada hal tersebut, dimana fokus pembangunan sumber daya manusia yang dimiliki oleh Indonesia juga menyertakan upaya membangun perempuan Indonesia (Kementrian Pemberdayaan Perempuan dan Perlindungan anak, 2019). Upaya untuk mengurangi ketimpangan gender pada perempuan sudah masuk agenda utama pembangunan sumber daya manusia di Indonesia. Meskipun belum dapat dikatakan sempurna, Indonesia saat ini sudah menunjukkan kemajuan yang baik dengan memberikan akses pendidikan yang sama pada anak laki-laki dan perempuan, sebagai tanda adanya upaya menghapuskan diskriminasi gender. Keadaan tersebut mampu memberikan kesempatan pada perempuan yang mempunyai potensi untuk membangun dirinya dan keluarganya menjadi lebih baik. Kontribusi perempuan dalam upaya peningkatan kesejahteraan, dapat dengan mudah terwujud jika mereka diberi hak yang sama dalam pendidikan dan pekerjaan.

Keterlibatan perempuan dalam dunia kerja di Indonesia mulai mengalami peningkatan dari tahun ke tahun meskipun belum merata pada setiap provinsi. Berdasarkan data dari BPS pada tahun 2018 provinsi Bali berhasil menduduki posisi tertinggi yang memiliki perempuan bekerja dengan persentase sebesar 69,84 persen dan yang terendah sebesar 38,68 persen pada provinsi Jawa Barat (KPPPA, 2019). Namun, kenaikan angka partisipasi kerja berbanding terbalik dengan semakin lebarnya kesenjangan rata-rata upah antara pekerja perempuan dan laki-laki di Indonesia. Pada data yang dirilis oleh BPS menunjukkan bahwa nampak ada kesenjangan rata-rata upah yang diterima oleh pekerja perempuan dengan laki-laki. Pada tahun 2015 rata-rata upah pekerja perempuan di Indonesia berada pada angka kurang lebih 1,6 juta, sedangkan rata-rata upah pekerja lakilaki sebesar kurang lebih 1,9 juta, ada selisih sebesar 0,3 juta. Pada tahun 2019 jarak tersebut semakin melebar dimana rata-rata upah pekerja perempuan yaitu kurang lebih 2,1 juta, sedangkan rata-rata upah pekerja laki-laki yaitu kurang lebih 2,7 juta ada selisih sebesar 0,6 juta. Adanya peningkatan rata-rata upah pekerja juga diikuti dengan semakin lebarnya jarak kesenjangan rata-rata upah pekerja antara laki-laki dan perempuan (BPS, 2019)

BPS memberikan keterangan keadaan tersebut dapat terjadi karena adanya kemungkinan diskriminasi gender dalam dunia kerja yang biasanya berupa dibatasinya akses pekerja perempuan untuk dapat mencapai jenjang karir yang lebih tinggi dan ditempatkannya pekerja perempuan pada posisi bawah karena dianggap tidak dapat berkontribusi maksimal dalam pekerjaan (KPPPA, 2019). Meskipun sudah banyak dijumpai perempuan yang menjadi pemimpin atau tokoh penting hal tersebut nyatanya tidak dapat merubah keadaan bahwa adanya pelebaran jarak antara rata-rata upah pekerja perempuan dengan laki-laki.

Terjunnya perempuan dalam dunia kerja mempunyai berbagai macam alasan, salah satunya yaitu mencari pendapatan untuk memenuhi kebutuhan hidup. Ada pula yang memutuskan terjun dalam dunia kerja untuk memenuhi 
passion atau minat yang dimiliki. Bagi perempuan yang memutuskan bekerja untuk memenuhi kebutuhannya, maka tujuan utama sebagai pekerja adalah untuk memperoleh kehidupan yang lebih baik dengan memperbaiki kondisi ekonominya. Pemenuhan kebutuhan pada setiap individu berhak dilakukan sebagai salah satu bentuk upaya mencapai kesejahteraan individu tersebut. Dalam upaya mencapai kesejahteraannya dengan bekerja, pekerja perempuan cenderung berkontribusi pada sektor formal. Hal itu terjadi karena sektor formal dirasa lebih aman dan menjamin bagi tenaga kerja perempuan dibandingkan dengan sektor informal (KPPPA, 2019). Sebagai salah satu kota dengan pusat perdagangan terbesar di Provinsi Bali, Denpasar memiliki sektor formal yang didominasi oleh pekerja perempuan, sektor tersebut adalah jasa pendidikan pada bidang guru. Kota Denpasar memiliki total 9.011 guru pada berbagai jenjang pendidikan, terdiri dari 2.521 guru laki-laki dan 6.490 guru perempuan (Kemendikbud, 2020).

Perempuan yang menjadi guru merupakan perempuan yang mempunyai kesempatan dapat menempuh pendidikan minimal menengah atas sehingga bisa diterima dan bekerja menjadi guru. Kesempatan tersebut membuat perempuan memiliki peran ganda yaitu meningkatkan perekonomiannya dengan bekerja dan membantu dalam mendidik generasi penerus bangsa. Keinginan perempuan bekerja menjadi guru untuk memperbaiki keadaan ekonominya, mempunyai hambatan dengan masih rendahnya angka kesejahteraan guru di Indonesia secara keseluruhan (KPPPA, 2019). Bagi guru yang berkesempatan menjadi guru dengan status Pegawai Negeri Sipil (PNS), mungkin sedikit dapat bernapas lega dengan adanya gaji rutin dan tunjangan yang terima. Berbeda dengan mereka yang belum berkesempatan untuk menjadi bagian dari guru berstatus pegawai negeri yang masih harus merasakan kesulitan dalam memenuhi kebutuhan karena gaji yang diterima tidak rutin atau dengan jumlah yang rendah. Upaya menyejahterakan guru Indonesia dapat sekaligus membantu dalam upaya menyejahterakan pekerja perempuan Indonesia yang dominan bekerja pada sektor jasa pendidikan.

Kesejahteraan dapat didefinisikan sebagai keadaan dimana terpenuhinya kebutuhan seseorang atau individu untuk menjalankan hidup. Tingkat kesejahteraan sendiri mengacu pada kualitas hidup seseorang yang tentunya berbeda antara satu dengan yang lainnya. Indonesia menjadikan tingkat kesejahteraan sebagai cerminan bagaimana keberhasilan pemerintah dalam menjalankan pemerintahannya. Berbagai upaya dilakukan pemerintah dengan mengeluarkan kebijakan-kebijakan yang dapat meningkatkan kualitas hidup dan kesejahteraan rakyatnya. Kesejahteraan rakyat yang sedang diupayakan meliputi banyak bidang yang difokuskan pada upaya pemenuhan kebutuhan untuk mencapai kualitas hidup yang layak.

Indonesia awalnya menggunakan Produk Domestik Bruto (PDB) sebagai tolok ukur tunggal untuk menentukan tingkat kesejahteraan. Anggapan bahwa semakin besar angka PDB suatu negara, maka semakin makmur dan sejahtera rakyatnya diperoleh karena PDB adalah indeks yang mengukur tentang Output perekonomian keseluruhan suatu negara. Namun, penggunaan PDB sebagai indikator untuk menggambarkan kesejahteraan memiliki beberapa keterbatasan. Pertama PDB tidak dapat menggambarkan keadaan yang sebenarnya terjadi saat adanya ketimpangan dalam masyarakat. Hal tersebut terjadi karena PDB disajikan 
dalam bentuk per kapita yang perhitungannya menggunakan statistik rata - rata (mean). Kedua, statistik perhitungan yang digunakan PDB gagal dalam menangkap apabila ada fenomena yang dapat memengaruhi kesejahteraan masyarakat (Rustia, 2012).

Pada akhirnya pengukuran tingkat kesejahteraan dilakukan berdasarkan tujuan pembangunan berkelanjutan atau (Sustainable Development Goals/ SDGs). Semangat pembangunan berkelanjutan sama dengan semangat tujuan pembangunan nasional yaitu kesejahteraan masyarakat yang tidak hanya melihat dari segi perekonomian saja tetapi juga memperhatikan kualitas hidup untuk kesejahteraan yang berkelanjutan. SDGs memberikan gagasan bahwa kesejahteraan itu terikat dengan gagasan untuk menghapus kemiskinan yang merusak, mengurangi kesetaraan, menegakkan hak asasi manusia, melestarikan lingkungan alam dan meningkatkan keamanan (Joseph \& McGregor, 2020).

Pengukuran tingkat kesejahteraan dapat dilihat dengan menggunakan sudut pandang subjektif dan objektif. Kesejahteraan subjektif melakukan pengukuran pada karakteristik kesejahteraan individu tersebut. Kesejahteraan objektif melakukan pengukuran dengan ditentukan oleh standar hidup, lingkungan eksternal, dan mengacu pada populasi yang ada pada negara tersebut (Zemtsov \& Osipova, 2016). Konsep kesejahteraan yang dilihat dengan mempertimbangkan kondisi seseorang, akan menghasilkan berbagai jenis kesejahteraan dengan karakteristik sesuai dengan kondisi individu tersebut. Jenis - jenis kesejahteraan yang dihasilkan yaitu kesejahteraan fisik, kesejahteraan psikologis (termasuk emosional dan mental), dan kesejahteraan sosial dan keuangan (Zemtsov \& Osipova, 2016).

Financial wellbeing atau kesejahteraan keuangan merupakan keadaan dimana seseorang memiliki persiapan dalam memenuhi kebutuhan keuangan di masa depan, dapat dikatakan mampu membayar kewajiban keuangan untuk saat ini dan masa depan, dan mampu menentukan pilihan untuk dapat menikmati hidupnya (Consumer Financial Protection Bureau, 2015). Persiapan yang dilakukan untuk memenuhi kebutuhan dan kewajiban finansial saat ini maupun yang akan datang dapat dilakukan oleh individu yang mempunyai dasar pengelolaan keuangan yang baik. Hal tersebut terjadi karena kesejahteraan finansial dapat tercapai apabila individu tersebut mampu mengelola aset yang dimiliki untuk dikembangkan sehingga dapat mencapai kesejahteraan finansial (Zemtsov \& Osipova, 2016).

Penelitian yang dilakukan oleh Mahdzan et al. (2019) mendefinisikan kesejahteraan keuangan subjektif merupakan kemampuan untuk mengendalikan keuangan yang dimiliki, mempunyai kapasitas menangani ketidakpastian keuangan, memenuhi kebutuhan, dan memiliki kebebasan untuk membuat pilihan finansial untuk menikmati hidupnya. Kesejahteraan keuangan juga dapat dilakukan pengukuran secara objektif, seperti dalam penelitian yang dilakukan oleh Mahdzan et al. (2019) menunjukkan bahwa pengukuran kesejahteraan keuangan dilakukan berdasarkan pada definisi konsep menyeluruh, dimana kesejahteraan keuangan objektif menggunakan pengukuran seperti tingkat utang, tingkat pendapatan, tabungan, dan bentuk lainnya. Namun, pada kesejahteraan 
keuangan subjektif dilakukan pengukuran persepsi diri tentang kebahagiaan dan kepuasan finansial.

Dalam upaya pencapaian kesejahteraan, berdasarkan hasil survei oleh Otoritas Jasa Keuangan (OJK) terkait indeks tingkat literasi dan tingkat inklusi keuangan pada tahun 2019 menggambarkan bahwa tingkat literasi keuangan pada laki-laki lebih unggul dibandingkan perempuan. Secara nasional tingkat literasi keuangan pada laki-laki sebesar 39,94 persen, sedangkan pada perempuan hanya sebesar 36,13 persen (SNLKI, 2019).

Literasi keuangan mencakup kemampuan dalam membedakan pilihan keuangan, membahas mengenai kondisi keuangan, masalah keuangan tanpa merasa tidak nyaman karena sudah memiliki pengetahuan yang mencukupi untuk merencanakan masa depan atau merespon peristiwa yang memengaruhi kondisi keuangan dan ekonomi secara menyeluruh (Yushita, 2017). Penelitian yang dilakukan oleh Tarigan (2017) juga menyampaikan fungsi dan manfaat dari adanya perencanaan keuangan. Fungsi perencanaan keuangan sendiri adalah untuk merencanakan keuangan masa yang akan datang sedini mungkin agar dapat mencapai tujuan kesejahteraan keuangan yang dicita - citakan dengan adanya pengelolaan keuangan yang baik. Adapun untuk manfaat keuangan sendiri salah satunya yaitu mendapatkan rasa aman dan bebas dari kekhawatiran keuangan dengan mengantisipasi kebutuhan biaya.

Chu et al., (2017) dalam penelitiannya menunjukkan literasi keuangan dan pemilihan portofolio dapat memengaruhi tingkat kesejahteraan keuangan rumah tangga. tingkat literasi keuangan yang tinggi mampu menggambarkan tingkat pengetahuan yang tinggi sehingga memberikan kesempatan untuk melakukan pengelolaan portofolio yang dapat memberikan hasil yang tinggi. Hal tersebut dapat memberikan keuntungan sehingga berkontribusi terhadap kesejahteraan keuangan rumah tangga tersebut. Penelitian yang dilakukan oleh Zemtsov \& Osipova (2016) juga mendefinisikan bahwa kesejahteraan keuangan merupakan perilaku keuangan dan aliran pendapatan yang dihasilkan, sehingga dapat disimpulkan terdapat faktor pendapatan yang menjadi komponen dalam perhitungan kesejahteraan.

Organisation for Economic Co-operation and Development atau OECD (2016) mendefinisikan literasi keuangan sebagai sebuah pengetahuan dan pemahaman terhadap konsep dan risiko keuangan, motivasi, keterampilan, dan kepercayaan diri dalam mengelola keuangan untuk diterapkan dalam kehidupan. Hal tersebut dilakukan untuk menghasilkan keputusan keuangan yang tepat, sehingga kesejahteraan keuangan individu dan masyarakat dapat meningkat. Literasi keuangan menurut (Palameta et al., 2016) merupakan pengetahuan keuangan yang berkembang dan menjadi keterampilan keuangan yang dimiliki seseorang, dimana keterampilan merupakan kemampuan mengimplementasikan pengetahuan yang dimiliki. Definisi literasi keuangan yang dikutip dari Otoritas Jasa Keuangan (OJK) cukup jelas menggambarkan bahwa tujuan dari adanya program pemerintah dalam upaya peningkatan literasi keuangan dan inklusi keuangan adalah untuk mencapai kesejahteraan keuangan (OJK, 2017). Pendapat tersebut didukung pula oleh Singh \& Kumar (2017) dalam penelitiannya yang meneliti literasi keuangan pada perempuan, hasil tersebut menunjukkan literasi 
keuangan mempumyai pengaruh besar terhadap kesejahteraan keuangan perempuan, hal tersebut karena tingkat literasi keuangan memengaruhi bagaimana seseorang akan berperilaku terhadap kondisi keuangannya. Haque \& Zulfiqar (2016) juga menunjukkan arah yang positif dan signifikan pengaruh literasi keuangan terhadap pemberdayaan dan kesejahteraan keuangan perempuan. Hal tersebut disebabkan perilaku pengambilan keputusan keuangan dilakukan berdasarkan pengetahuan dan keterampilan yang dimiliki oleh perempuan, dan hasil keputusan yang berdasarkan pada literasi keuangan lebih memudahkan dalam mencapai kesejahteraan keuangan. Berdasarkan pengertian tersebut literasi keuangan dapat didefinisikan sebagai sebuah keterampilan dalam menentukan keputusan keuangan berdasarkan pengetahuan keuangan yang dimiliki, sehingga dapat bermanfaat terhadap upaya pencapaian kesejahteraan keuangan, pernyataan tersebut didukung oleh penelitian sebelumnya yang menyatakan bahwa literasi keuangan berpengaruh atau berperan terhadap kesejahteraan keuangan(Adam et al., 2017; Aulia et al., 2019; Boon et al., 2011; Lin et al., 2017).

$\mathrm{H}_{1}$ : Literasi Keuangan memiliki pengaruh positif signifikan terhadap kesejahteraan keuangan.

(Boon et al., 2011) memaparkan hasil penelitian dimana perencanaan keuangan individu yang dipengaruhi tingkat literasi keuangan dapat menjadi solusi terhadap pengelolaan keuangan yang berdampak pada stabilitas kondisi keuangan. Hal tersebut dapat membantu dalam pencapaian kesejahteraan keuangan. Kumar et al. (2019) melakukan penelitian terkait perencanaan keuangan dimana yang menjadi subjek penelitian adalah pekerja perempuan yang melakukan perencanaan keuangan untuk pensiun. Upaya perencanaan keuangan pensiun dilakukan untuk mencapai kesejahteraan keuangan untuk masa depan pekerja perempuan. Adam et al. (2017) pada penelitiannya yang membahas mengenai literasi keuangan, perencanaan keuangan pensiun, dan dukungan keluarga yang berpengaruh terhadap kesejahteraan, menunjukkan hasil bahwa perencanaan keuangan pensiun berpengaruh positif terhadap kesejahteraan.

Pada penelitian Aulia et al. (2019) perencanaan keuangan didefinisikan sebagai upaya mengatur kewajiban, pengeluaran sehari - hari, tabungan, dana pendidikan, dan dana pensiun, bukan hanya tentang mengatur investasi dan menambah kekayaan. Perencanaan keuangan memerlukan penilaian yang komprehensif karena mempertemukan status keuangan saat ini dan masa depan, dan proses ini terus berkembang dikarenakan adanya tujuan hidup (Kumar et al., 2019). Penelitian yang dilakukan oleh Brahmana \& Brahmana (2016) mengemukakan perencanaan keuangan yang dilakukan oleh mantan pekerja imigran Indonesia di Malaysia cenderung buruk sehingga mantan pekerja tersebut tidak mempunyai dana dan tidak tercapainya kesejahteraan keuangan yang baik karena tidak adanya perencanaan keuangan dalam mengelola pendapatannya selama menjadi pekerja imigran. Individu yang ingin memetakan cara - cara mencapai kesejahteraan keuangan maka perlu melakukan perencanaan keuangan Berdasarkan penelitian yang dilakukan Yohanna \& Maya (2018) menunjukkan bahwa manajemen keuangan yang baik dapat meningkatkan kesejahteraan keluarga. Perencanaan keuangan pada mereka yang terikat status pernikahan memberikan pengaruh positif terhadap kesejahteraan keuangan rumah tangga 
(Fulda \& Lersch, 2018). Kumar et al. (2019) turut mendukung pernyataan tersebut pada penelitiannya, dimana perencanaan keuangan pada perempuan berpengaruh positif terhadap kesejahteraan keuangan dimasa yang akan datang salah satunya yaitu dana pensiun.

$\mathrm{H}_{2}$ : Perencanaan keuangan berpengaruh positif secara signifikan terhadap kesejahteraan keuangan.

Pendapatan dapat bersumber dari gaji, return investasi dan sebagainya. Penelitian yang dilakukan Purwidianti \& Mudjiyanti (2016)mendefinisikan tingkat pendapatan adalah total pendapatan kotor individu yang berasal dari upah, gaji, return investasi, dan usaha yang dimiliki individu tersebut. Tingkat pendapatan individu memengaruhi bagaimana individu akan menggunakan sumber dananya. Penelitian yang dilakukan oleh Indrayani (2018) memaparkan bahwa semakin tinggi pendapatan individu maka akan sulit dalam mengatur keuangannya dan begitu pula sebaliknya. Hal ini terjadi dikarenakan adanya faktor keinginan dan kepuasan yang ingin dipenuhi. Individu yang berpendapatan rendah cenderung lebih mudah dalam mengelola keuangan dikarenakan kemampuan dalam memenuhi kebutuhan terbatas, sehingga membatasi pengeluarannya dengan menggunakan skala prioritas kebutuhan.

Pendapatan merupakan suatu aliran dana yang diterima bersumber dari kegiatan bekerja dan dapat juga berasal dari pengelolaan aset. Penelitian yang dilakukan oleh (Brown \& Gray, 2016; Joo \& Grable, 2004; Kay, 2017) menghasilkan pernyataan yang sama dimana usia, status pernikahan, pendidikan terakhir, pendapatan, literasi keuangan, perilaku keuangan, dan tingkat tekanan keuangan memengaruhi kesejahteraan keuangan. Pendapatan merupakan suatu aliran dana yang diterima bersumber dari kegiatan bekerja dan dapat juga berasal dari pengelolaan aset. Brüggen et al. (2017) menyebutkan bahwa pendapatan merupakan salah satu faktor yang berpengaruh pada kesejahteraan keuangan. Hal ini karena tingkat pendapatan menjadi faktor objektif utama yang dikelola untuk bisa mencapai kesejahteraan keuangan baik secara independen maupun dikombinasikan dengan faktor objektif yang lain. Penelitian yang dilakukan Siregar \& Ritonga (2019) menunjukkan bahwa tingkat pendapatan berpengaruh signifikan terhadap kesejahteraan sosial, dimana kesejahteraan sosial yang meliputi kesejahteraan keuangan. Pada penelitian yang dilakukan Zemtsov \& Osipova (2016) juga menyebutkan bahwa pendapatan bersama dengan literasi keuangan, preferensi, dan nilai - nilai keuangan membentuk kesejahteraan keuangan. Semakin tinggi pendapatan maka akan semakin banyak opsi dalam melakukan pengelolaan keuangan, sehingga kesejahteraan keuangan dapat tercapai.

$\mathrm{H}_{3}$ : Pendapatan memiliki pengaruh positif secara signifikan terhadap kesejahteraan keuangan 


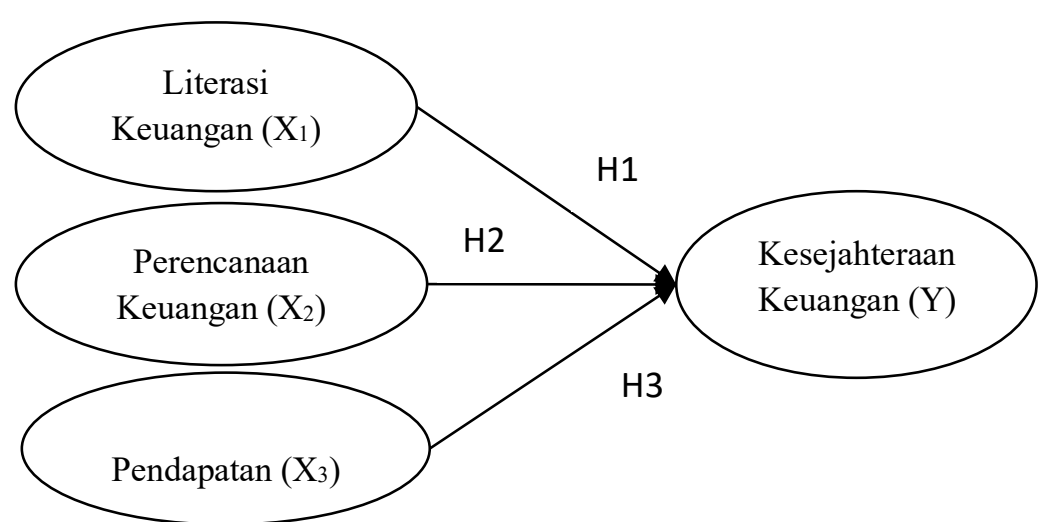

Gambar 1. Kerangka Konseptual

\section{METODE PENELITIAN}

Penelitian ini dilakukan dengan pendekatan secara kuantitatif yang berbentuk asosiatif untuk mengetahui faktor - faktor yang memengaruhi kesejahteraan keuangan pada guru perempuan yang ada di Denpasar. Lokasi penelitian merupakan wilayah dimana penelitian akan dilakukan. Dalam penelitian ini lokasi penelitian berada pada sekolah di kota Denpasar. Dalam penelitian multivariat ukuran sampel lebih baik memiliki jumlah minimal 10 kali dari variabel yang digunakan atau lebih besar dari jumlah sampel studi (Sekaran, 2006:160). Dalam aturan umum ukuran sampel direkomendasikan rasio 10:1 kasus untuk setiap variabel (Hair et al, 2006). Oleh karena itu, dengan jumlah keseluruhan indikator 11, jumlah parameter sampel yang digunakan minimal 110 responden. Teknik penentuan sampel yang digunakan adalah teknik nonprobability sampling dengan jenis adalah sampling kuota, merupakan teknik pemilihan sampel yang dari populasi yang mempunyai ciri-ciri tertentu hingga mencapai jumlah yang dibutuhkan.

Populasi distrata berdasarkan jenjang pendidikan, kemudian ditentukan kuota (jatah) untuk setiap strata secara proporsional. Jumlah kuota sampel yaitu sebesar 110 sampel yang didistribusikan secara merata 11 kelompok pendidikan yang menjadi objek observasi pada Tabel 1.

Tabel 1.

Penentuan Sampel

\begin{tabular}{clrllllll}
\hline No. & Jenjang Pendidikan & \multicolumn{7}{c}{ Proporsional Sampel } \\
\hline 1 & TK & $1108 / 6490$ & x & 110 & $=$ & 18.78 & $=$ & 19 \\
2 & KB & $62 / 6490$ & x & $110=$ & 1.05 & $=$ & 1 \\
3 & TPA & $22 / 6490$ & x & $110=$ & 0.37 & $=$ & 0 \\
4 & SPS & $5 / 6490$ & x & 110 & $=$ & 0.08 & $=$ & 0 \\
5 & PKMB & $64 / 6490$ & x & 110 & $=$ & 1.08 & $=$ & 1 \\
6 & SKB & $9 / 6490$ & x & 110 & $=$ & 0.15 & $=$ & 0 \\
7 & SD & $2828 / 6490$ & x & 110 & $=$ & 47.93 & $=$ & 48 \\
\hline Bersambung... & & & & & & &
\end{tabular}


Lanjutan Tabel 1.

\begin{tabular}{|c|c|c|c|c|c|c|c|c|}
\hline No. & Jenjang Pendidikan & \multicolumn{7}{|c|}{ Proporsional Sampel } \\
\hline 8 & SMP & $1119 / 6490$ & $\mathrm{x}$ & 110 & $=$ & 18.97 & $=$ & 19 \\
\hline 9 & SMA & $561 / 6490$ & $\mathrm{x}$ & 110 & $=$ & 9.51 & $=$ & 10 \\
\hline 10 & SMK & $658 / 6490$ & $\mathrm{x}$ & 110 & $=$ & 11.15 & $=$ & 11 \\
\hline 11 & SLB & $54 / 6490$ & $\mathrm{x}$ & 110 & $=$ & 0.92 & $=$ & 1 \\
\hline & & Jumlah & & & & & & 110 \\
\hline
\end{tabular}

Sumber: Data diolah, 2020

Penelitian ini dalam pengumpulan datanya menggunakan kuesioner dan wawancara. Penyebaran kuesioner dilakukan dengan dua cara, pertama peneliti memberikan langsung kuesioner dan peneliti membantu menjelaskan maksud pernyataan untuk memastikan responden mengerti dan menjawab dengan tepat. Kedua dengan menunjukkan link person untuk membantu menyebarkan kuesioner, setelah diisi kuesioner dapat dikembalikan langsung pada link person.

Penelitian ini menggunakan tiga variabel independen (literasi keuangan, perencanaan keuangan, dan pendapata) dan satu variabel dependen (kesejahteraan keuangan). Keempat variabel ini diukur dengan menggunakan indikator reflektif. Skala likert dengan rentang nilai 1 (tidak setuju) hingga 5 (sangat setuju) digunakan untuk mengukup indikator variabel pada penelitian ini.

Kesejahteraan keuangan menggambarkan kemapanan keuangan pada guru perempuan yang ada di sekolah di Kota Denpasar. Kesejahteraan keuangan menunjukkan individu memiliki kondisi keuangan yang baik. Kesejahteraan keuangan pada penelitian ini diukur dengan menggunakan indikator memiliki dana darurat, investasi, dan asuransi. Literasi keuangan menggambarkan pengetahuan dan kemampuan individu dalam mengelola keuangannya yang dapat memengaruhi tingkat kesejahteraan keuangan pada guru perempuan. Literasi keuangan diukur dengan indikator mengetahui produk dan layanan jasa keuangan, kemampuan keuangan, dan pengelolaan keuangan Perencanaan keuangan merupakan langkah untuk mendapatkan keuntungan atas pengelolaan keuangan untuk saat ini dan masa depan, sehingga hal tersebut dapat berpengaruh terhadap kesejahteraan keuangan. Indikator perencanaan keuangan yang digunakan yaitu mengelola asuransi, mengelola investasi, dan mengelola dana pensiun. Pendapatan adalah penghasilan bersih yang diperoleh oleh individu sehingga besarannya berpengaruh terhadap tingkat kesejahteraan pekerja perempuan di Kota Denpasar. Indikator pendapatan yang digunakan adalah pendapatan utama dan pendapatan lain-lain

Teknik analisis data yang digunakan pada penelitian ini ada teknik analisis data statistik deskriptif dan statistik inferensial. Statistik deskriptif menganalisis data dengan menggambarkan data kemudian mendeskripsikan dengan apa adanya tanpa ada tambahan untuk menggeneralisir kesimpulan pada populasi (Sugiyono, 2017: 232). Bentuk statistik inferensial yang digunakan yaitu Partial Least Square (PLS) dengan menggunakan software Partial Least Square (PLS) versi 3.0 (Ghozali dan Latan, 2015). 


\section{HASIL DAN PEMBAHASAN}

Uji instrumen penelitian dilakukan dengan uji validitas dan reliabilitas, uji validitas untuk mengukur valid atau tidaknya kuesioner yang digunakan. Uji reliabilitas untuk mengukur apakah kuesioner dapat digunakna beberapa kali untuk mengukur objek yang sama akan menghasilkan data yang sama. Sebelum kuesioner dikirimkan kepada responden yang sesungguhnya, pernyataan pernyataan di dalam kuesioner ini diuji coba kepada 30 orang responden guru perempuan.

Uji validitas ditentukan dengan pearson correlation, jika koefisien korelasi masing-masing item $>0,30$, maka dapat dinyatakan valid. Pada penelitian ini hasil uji validitas instrumen kedua puluh item pernyataan menunjukkan koefisien korelasi $>0,30$, maka seluruh item pernyataan pada kuesioner valid. Uji reliabilitas yang ditentukan dengan uji statistik Cronbach Alpha menunjukkan nilai Cronbach Alpha lebih besar 0,70 yang artinya variabel dikatakan reliabel atau andal. Hasil dari pengujian instrumen penelitian tersaji pada Tabel 2.

\section{Tabel 2.}

Hasil Uji Instrumen

\begin{tabular}{|c|c|c|c|c|}
\hline Variabel & Item & Valid & Cronbach Alpha & Keterangan \\
\hline \multirow[t]{8}{*}{ Literasi Keuangan } & $\mathrm{X} 1.1$ & 0,671 & 0,770 & Valid dan Reliabel \\
\hline & $\mathrm{X} 1.2$ & 0,742 & & \\
\hline & $\mathrm{X} 1.3$ & 0,860 & & \\
\hline & $\mathrm{X} 1.4$ & 0,752 & & \\
\hline & $\mathrm{X} 1.5$ & 0,767 & & \\
\hline & X1.6 & 0,809 & & \\
\hline & $\mathrm{X} 1.7$ & 0,891 & & \\
\hline & $\mathrm{X} 1.8$ & 0,850 & & \\
\hline \multirow[t]{5}{*}{ Perencanaan Keuangan } & $\mathrm{X} 2.1$ & 0,730 & 0,805 & Valid dan Reliabel \\
\hline & $\mathrm{X} 2.2$ & 0,882 & & \\
\hline & $\mathrm{X} 2.3$ & 0,701 & & \\
\hline & $\mathrm{X} 2.4$ & 0,796 & & \\
\hline & $\mathrm{X} 2.5$ & 0,881 & & \\
\hline \multirow[t]{4}{*}{ Pendapatan } & X3.1 & 0,683 & 0,765 & Valid dan Reliabel \\
\hline & $\mathrm{X} 3.2$ & 0,730 & & \\
\hline & X3.3 & 0,801 & & \\
\hline & X 3.4 & 0,786 & & \\
\hline \multirow[t]{3}{*}{ Kesejahteraan Keuangan } & Y1 & 0,747 & 0,812 & Valid dan Reliabel \\
\hline & Y2 & 0,767 & & \\
\hline & Y3 & 0,794 & & \\
\hline
\end{tabular}

Sumber: Data primer diolah, 2020

Pada Tabel 3. menggambarkan karakteristik dari 110 responden yang sudah berkontribusi dalam penelitian ini. Semua responden telah mengisi identitas secara lengkap meliputi pendidikan terakhir, status pernikahan, status kepegawaian, umur dan kondisi keuangan.

Responden dengan jenjang pendidikan terakhir pada jenjang S1 sebanyak 89 orang (80,91 Persen), sisanya pada jenjang pendidikan SMA sederajat, Diploma, dan S2. Data tersebut menggambarkan tingkat Pendidikan terakhir yang 
mendominasi pada responden yaitu pada jenjang S1 dengan jumlah responden yang besar.

Responden yang status pernikahan kawin sebanyak 84 orang (76,36 persen). Pada data tersebut mayoritas responden mempunyai status pernikahan kawin. Responden dengan status sebagai guru kontrak sebanyak 37 orang $(33,64$ persen), honorer sebanyak 31 orang (28,18 persen), dan pegawai negeri sipil (PNS sebanyak 42 orang $(38,18$ persen). Data tersebut menginformasikan bahwa mayoritas responden menjadi guru dengan status bukan PNS yaitu honorer dan kontrak.

Responden dengan usia 21 sampai 30 tahun ada 45 orang (40,91 persen), 31 sampai 40 tahun ada 22 orang (20,00 persen), 41 sampai 50 tahun ada 14 orang (12,73 persen), dan 29 orang (26,36 persen) responden yang berusia 51 sampai 60 tahun. Pada data tersebut diketahui responden didominasi guru dengan usia antara 21 sampai 30 tahun. Responden dengan pendapatan setiap bulannya $<2.000 .000$ rupiah sebanyak 55 orang (50,00 persen), 2.000.001 sampai 3.000.000 rupiah sebanyak 18 orang (16,36 persen), 3.000.001 sampai 4.000.000 rupiah sebanyak 16 orang (14,55 persen), dan $>4.000 .000$ rupiah sebanyak 21 orang $(19,09$ persen). Hal ini menunjukkan bahwa mayoritas responden memiliki pendapatan $<$ 2.000.000 rupiah yang kurang dari upah minimum provinsi Bali yang ditetapkan Keputusan Gubernur Bali Nomor 2193/03-G/HK/2019 dan berlaku pada 1 Januari 2020 sebesar Rp 2.494.000.

Responden yang dengan pengeluaran setiap bulannya $<1.000 .000$ rupiah sebanyak 13 orang (11,82 persen), 1.000.001 sampai 2.000.000 rupiah sebanyak 49 orang $(44,55$ persen) total 61 orang $(56,37$ persen). Hal ini menunjukkan bahwa mayoritas responden memiliki pengeluaran setiap bulannya berkisar pada $<1.000 .000$ sampai 2.000.000 rupiah. Responden yang memiliki kewajiban < 5.000.000 rupiah sebanyak 66 orang (60,00 persen), 5.000.001 sampai 10.000.000 rupiah sebanyak 16 orang (14,55 persen), dan $>10.000 .000$ rupiah sebanyak 28 orang $(25,45$ persen). Hal ini menunjukkan bahwa mayoritas responden memiliki kewajiban sebesar $<5.000 .000$ rupiah. Responden yang memiliki aset dengan total $<10.000 .000$ rupiah sebanyak 67 orang $(60,91$ persen $), 10.000 .001$ sampai 50.000 .000 rupiah sebanyak 31 orang (28,18 persen), 50.000.001 sampai 100.000.000 rupiah sebanyak 5 orang (4,55 persen), dan $>100.000 .000$ rupiah sebanyak 7 orang $(6,36$ persen). Hal ini menunjukkan bahwa mayoritas responden memiliki aset yang bernilai $<10.000 .000$ rupiah.

Tabel 3.

Karakteristik Responden

\begin{tabular}{|c|c|c|c|c|}
\hline No & Karakteristik & Pilihan & Jumlah (Orang) & Persentase (\%) \\
\hline \multirow{5}{*}{1} & \multirow{4}{*}{ Pendidikan } & SMA & 3 & 2.73 \\
\hline & & Diploma & 4 & 3.64 \\
\hline & & S1 & 89 & 80.91 \\
\hline & & $\mathrm{S} 2$ & 14 & 12.73 \\
\hline & Jumlah & & 110 & 100.00 \\
\hline \multirow{2}{*}{2} & \multirow{2}{*}{ Status pernikahan } & Cerai Mati & 2 & 1.82 \\
\hline & & Belum Kawin & 24 & 21.82 \\
\hline
\end{tabular}

Bersambung... 
Lanjutan Tabel 3.

\begin{tabular}{|c|c|c|c|c|}
\hline No & Karakteristik & Pilihan & Jumlah (Orang) & Persentase (\%) \\
\hline & & Kawin & 84 & 76.36 \\
\hline & Jumlah & & 110 & 100.00 \\
\hline \multirow{4}{*}{3} & \multirow{3}{*}{ Status kepegawaian } & Kontrak & 37 & 33.64 \\
\hline & & Honorer & 31 & 28.18 \\
\hline & & PNS & 42 & 38.18 \\
\hline & Jumlah & & 110 & 100.00 \\
\hline \multirow{5}{*}{4} & \multirow{4}{*}{ Umur } & $21-30$ & 45 & 40.91 \\
\hline & & $31-40$ & 22 & 20.00 \\
\hline & & $41-50$ & 14 & 12.73 \\
\hline & & $51-60$ & 29 & 26.36 \\
\hline & Jumlah & & 110 & 100.00 \\
\hline \multirow{5}{*}{5} & \multirow{4}{*}{$\begin{array}{l}\text { Pendapatan pribadi } \\
\text { (perbulan) }\end{array}$} & $<2.000 .000$ & 55 & 50.00 \\
\hline & & $2.000 .001-3.000 .000$ & 18 & 16.36 \\
\hline & & $3.000 .001-4.000 .000$ & 16 & 14.55 \\
\hline & & $>4.000 .000$ & 21 & 19.09 \\
\hline & Jumlah & & 110 & 100.00 \\
\hline \multirow{5}{*}{6} & \multirow{4}{*}{$\begin{array}{l}\text { Pengeluaran pribadi } \\
\text { (perbulan) }\end{array}$} & $<1.000 .000$ & 13 & 11.82 \\
\hline & & $1.000 .001-2.000 .000$ & 49 & 44.55 \\
\hline & & $2.000 .001-3.000 .000$ & 18 & 16.36 \\
\hline & & $>3.000 .000$ & 30 & 27.27 \\
\hline & Jumlah & & 110 & 100.00 \\
\hline \multirow{4}{*}{7} & \multirow{3}{*}{$\begin{array}{l}\text { Kewajiban atau utang } \\
\text { yang dimiliki }\end{array}$} & $<5.000 .000$ & 66 & 60.00 \\
\hline & & $5.000 .001-10.000 .001$ & 16 & 14.55 \\
\hline & & $>10.000 .000$ & 28 & 25.45 \\
\hline & Jumlah & & 110 & 100.00 \\
\hline \multirow{5}{*}{8} & \multirow{4}{*}{$\begin{array}{l}\text { Nilai total aset yang } \\
\text { dimiliki }\end{array}$} & $<10.000 .000$ & 67 & 60.91 \\
\hline & & $10.000 .001-50.000 .001$ & 31 & 28.18 \\
\hline & & $50.000 .001-100.000 .001$ & 5 & 4.55 \\
\hline & & $>100.000 .001$ & 7 & 6.36 \\
\hline & Jumlah & & 110 & 100.00 \\
\hline
\end{tabular}

Sumber: Data primer diolah, 2020

Pada Tabel 4 menunjukkan nilai minimum variabel literasi keuangan 1,00, dengan nilai maksimum 4,67, dan nilai rata-rata 3,091. Nilai rata-rata sebesar 3,091 mendekati nilai maksimal yang artinya guru-guru perempuan di Kota Denpasar cenderung memiliki tingkat literasi yang cukup. Nilai rata-rata keseluruhan literasi keuangan cenderung mendekati nilai maksimum sehingga dapat dikatakan tingkat literasi keuangan sampel cenderung cukup tinggi. Deviasi standar literasi keuangan menunjukkan nilai sebesar 0,936. Oleh karena nilai deviasi standarnya yang lebih rendah dari nilai rata-rata maka memiliki rentang persebaran data Literasi Keuangan cukup dekat. 
Table 4.

Hasil Statistik Deskriptif

\begin{tabular}{|c|c|c|c|c|c|}
\hline Variabel & \begin{tabular}{|l|} 
Jumlah \\
Sampel
\end{tabular} & $\begin{array}{l}\text { Rata- } \\
\text { rata }\end{array}$ & $\begin{array}{l}\text { Nilai } \\
\text { Minimum }\end{array}$ & $\begin{array}{l}\text { Nilai } \\
\text { Maksimal }\end{array}$ & $\begin{array}{l}\text { Deviasi } \\
\text { Standar }\end{array}$ \\
\hline Literasi Keuangan & 110 & 3,091 & 1,00 & 4,67 & 0,936 \\
\hline Pengetahuan & & & & & \\
\hline Keuangan & 110 & 3,045 & 1,00 & 5,00 & 1,082 \\
\hline Pengelolaan Keuangan & 110 & 3,173 & 1,00 & 5,00 & 1,008 \\
\hline Kemampuan Keuangan & 110 & 3,055 & 1,00 & 5,00 & 1,077 \\
\hline Perencanaan Keuangan & 110 & 3,094 & 1,00 & 5,00 & 0,981 \\
\hline Mengelola Asuransi & 110 & 3,045 & 1,00 & 5,00 & 1,107 \\
\hline Mengelola Investasi & 110 & 3,091 & 1,00 & 5,00 & 1,180 \\
\hline Mengelola Pensiun & 110 & 3,145 & 1,00 & 5,00 & 1,143 \\
\hline Pendapatan & 110 & 3,041 & 1,00 & 5,00 & 1,064 \\
\hline Pendapatan Utama & 110 & 3,345 & 1,00 & 5,00 & 1,209 \\
\hline Pendapatan lain-lain & 110 & 2,736 & 1,00 & 5,00 & 1,173 \\
\hline Kesejahteraan Keuangan & 110 & 3,361 & 1,33 & 4,67 & 0,814 \\
\hline Dana Darurat & 110 & 3,345 & 1,00 & 5,00 & 0,909 \\
\hline Investasi & 110 & 3,391 & 1,00 & 5,00 & 0,945 \\
\hline Asuransi & 110 & 3,345 & 1,00 & 5,00 & 0,909 \\
\hline
\end{tabular}

Nilai minimum variabel perencanaan keuangan 1,00, nilai maksimum 5,00, dan nilai rata-rata 3,094. Dengan nilai rata-rata 3,094 mendekati nilai maksimal artinya guru-guru perempuan di Kota Denpasar cenderung melakukan kegiatan perencanaan keuangan dalam kehidupannya. Nilai rata-rata keseluruhan perencanaan keuangan cenderung mendekati nilai maksimum sehingga dapat dikatakan kemampuan perencanaan keuangan sampel cenderung cukup tinggi. Deviasi standar perencanaan keuangan menunjukkan nilai sebesar 0,981 . Oleh karena nilai deviasi standarnya lebih besar dari nilai rata-rata, maka rentang persebaran data perencanaan keuangan cukup dekat.

Nilai minimum variabel pendapatan 1,00 , nilai maksimum 5,00 , dan nilai rata-rata 3,041. Dengan nilai rata-rata 3,041 yang mendekati nilai maksimal artinya guru-guru perempuan di Kota Denpasar cenderung memiliki tingkat pendapatan yang cukup. Nilai rata-rata pendapatan cenderung mendekati nilai maksimum sehingga dapat dikatakan tingkat pendapatan sampel cenderung cukup tinggi. Deviasi standar pendapatan menunjukkan nilai sebesar 1,064. Oleh karena nilai deviasi standarnya lebih rendah dari nilai rata-rata. Maka rentang persebaran data pendapatan cukup dekat.

Nilai minimum variabel kesejahteraan keuangan 1,33, nilai maksimum 4,67, dan nilai rata-rata 3,361. Dengan nilai rata-rata sebesar 3,361 yang mendekati nilai maksimal artinya guru-guru perempuan di Kota Denpasar cenderung memiliki tingkat kesejahteraan keuangan yang cukup tinggi. Nilai rata-rata keseluruhan kesejahteraan keuangan cenderung mendekati nilai maksimum sehingga dapat dikatakan tingkat kesejahteraan keuangan sampel cenderung cukup tinggi. Deviasi standar kesejahteraan keuangan menunjukkan nilai sebesar 0,814. Oleh karena nilai deviasi standarnya lebih rendah dari nilai rata-rata, maka rentang persebaran data kesejahteraan keuangan cukup dekat. 
Penelitian melakukan analisis dengan PLS-SEM, proses analisis ada dua sub model, yaitu outer model (model pengukuran) dan structural model (model structural). Analisis evaluasi outer model dilakukan untuk menilai validitas dan reliabilitas model yang dapat dievaluasi melalui validitas konvergen, validitas diskriminan, composite reliability serta cronbach alpha (Ghozali dan Latan, 2015: 73).

Validitas konvergen memiliki prinsip bahwa pada suatu konstruk, pengukurpengukurnya harus memiliki korelasi yang tinggi dengan konstruk tersebut. Uji validitas konvergen pada indikator variabel menggunakan program SmartPLS 3.0 dapat dilihat pada nilai loading factor atau dapat juga dilihat dari nilai Average variance extracted (AVE). Loading factor hasil dari output SmartPLS menunjukkan 11 indikator memiliki nilai loading factor $>0,7$. Hal ini berarti indikator pengetahuan produk keuangan, pengelolaan keuangan, kemampuan keuangan, mengelola asuransi, mengelola investasi, mengelola dana pensiun, pendapatan utama, pendapatan lain-lain, dana pensiun, investasi dan asuransi yang diharapkan adalah valid dan memenuhi validitas Convergen.

Nilai $A V E$ dari tiap-tiap variabel harus $>0,5$, artinya indikator dalam penelitian ini adalah valid dan telah memenuhi validitas konvergen. Adapun Output dari loading factor AVE disajikan pada Tabel 5.

Tabel 5.

Hasil Output Loading Factor dan Average Variance Extracted

\begin{tabular}{|c|c|c|c|c|c|}
\hline Variabel & $\begin{array}{l}\text { loading } \\
\text { factor }\end{array}$ & $\begin{array}{l}\text { Average } \\
(A V E)\end{array}$ & Variance & Extracted & Keterangan \\
\hline Literasi Keuangan & & & & 0,786 & Valid \\
\hline LK1 & 0,913 & & & & \\
\hline LK2 & 0,873 & & & & \\
\hline LK3 & 0,872 & & & & \\
\hline Perencanaan Keuangan & & & & 0,736 & Valid \\
\hline PK1 & 0,839 & & & & \\
\hline PK2 & 0,867 & & & & \\
\hline PK3 & 0,867 & & & & \\
\hline Pendapatan & & & & 0,798 & Valid \\
\hline P1 & 0,902 & & & & \\
\hline $\mathrm{P} 2$ & 0,884 & & & & \\
\hline Kesejahteraan Keuangan & & & & 0,784 & Valid \\
\hline KK1 & 0,884 & & & & \\
\hline KK2 & 0,896 & & & & \\
\hline KK3 & 0,875 & & & & \\
\hline
\end{tabular}

Validitas diskriminan berprinsip bahwa pengukur-pengukur dari sebuah konstruk yang digunakan pada konstruk berbeda seharusnya tidak korelasi tinggi. Validitas diskriminan diukur dengan nilai cross loading. Nilai cross loading tiaptiap indikator harus lebih tinggi daripada indikator lainnya dari variabel laten yang 
diukur, artinya indikator dalam penelitian ini adalah valid dan telah memenuhi validitas diskriminan.

Tabel 6.

Hasil Pengukuran Validitas Diskriminan dengan Cross Loadings

\begin{tabular}{lrrrr}
\hline & $\begin{array}{c}\text { Kesejahteraan } \\
\text { Keuangan (Y) }\end{array}$ & $\begin{array}{r}\text { Literasi Keuangan } \\
\text { (X1) }\end{array}$ & $\begin{array}{r}\text { Perencanaan } \\
\text { Keuangan (X2) }\end{array}$ & Pendapatan (X3) \\
\hline Y.1 & $\mathbf{0 , 8 8 4}$ & 0,782 & 0,776 & 0,632 \\
Y.2 & $\mathbf{0 , 8 9 6}$ & 0,751 & 0,768 & 0,688 \\
Y.3 & $\mathbf{0 , 8 7 5}$ & 0,768 & 0,712 & 0,634 \\
X1.1 & 0,785 & $\mathbf{0 , 9 1 3}$ & 0,639 & 0,584 \\
X1.2 & 0,798 & $\mathbf{0 , 8 7 3}$ & 0,709 & 0,601 \\
X1.3 & 0,716 & $\mathbf{0 , 8 7 2}$ & 0,589 & 0,542 \\
X2.1 & 0,707 & 0,559 & $\mathbf{0 , 8 3 9}$ & 0,515 \\
X2.2 & 0,775 & 0,684 & $\mathbf{0 , 8 6 7}$ & 0,698 \\
X2.3 & 0,701 & 0,632 & $\mathbf{0 , 8 6 7}$ & 0,525 \\
X3.1 & 0,683 & 0,641 & 0,570 & $\mathbf{0 , 9 0 2}$ \\
X3.2 & 0,630 & 0,518 & 0,648 & $\mathbf{0 , 8 8 4}$ \\
\hline
\end{tabular}

Sumber: Data primer diolah, 2020

Uji selanjutnya yang dilakukan adalah uji reliabilitas, dilakukan untuk memastikan bahwa konstruk memiliki konsistensi, ketepatan, dan akurat dalam mengukur konstruk. Uji reliabilitas suatu konstruk dengan indikator reflektif dapat dengan melihat nilai Cronbach's Alpha dan Composite Reliability (Ghozali dan Latan, 2015: 75). Nilai cronbach alpha pada setiap variabel harus $>0,7$ sehingga dapat dikatakan indikator tersebut konsisten dan akurat.

Tabel 7.

Hasil Output Composite Reliability dan Cronbach's Alpha

\begin{tabular}{lcc}
\hline \multicolumn{1}{c}{ Konstruk } & $\begin{array}{c}\text { Nilai Composite } \\
\text { Reliability }\end{array}$ & $\begin{array}{c}\text { Nilai Cronbach } \\
\text { Alpha }\end{array}$ \\
\hline Kesejahteraan Keuangan (Y) & 0,916 & 0,862 \\
Literasi Keuangan (X1) & 0,917 & 0,864 \\
Perencanaan Keuangan (X2) & 0,893 & 0,820 \\
Pendapatan (X3) & 0,888 & 0,747 \\
\hline
\end{tabular}

Sumber: Data primer diolah, 2020

Menilai model struktural dilakukan pada variabel laten endogen sebagai kekuatan prediksi dari model struktural dengan melihat nilai $R$-square $\left(\mathrm{R}^{2}\right)$ (Ghozali dan Latan, 2015: 78). Nilai $\mathrm{R}^{2}$ pengaruh literasi keuangan, perencanaan keuangan, dan pendapatan pada kesejahteraan keuangan sebesar 0,864, artinya sebesar 86,4 persen keputusan investasi dipengaruhi oleh literasi keuangan, perencanaan keuangan, dan pendapatan, sedangkan $13,6 \%$ oleh variabel lain di luar variabel yang diteliti. Nilai $R$-square sebesar 0,864 juga menunjukkan bahwa model kuat. Pengujian hipotesis dilakukan dengan melihat nilai koefisien parameter dan nilai signifikansi $\mathrm{T}$ statistik. Adapun hasil analisis disajikan pada 
Tabel 8 dan Gambar 2. Persamaan regresi dapat dibuat berdasarkan pada Tabel 8 dan Gambar 2 seperti berikut:

$$
\mathrm{Y}=0,473 \cdot \mathrm{X} 1+0,158 \cdot \mathrm{X} 2+0,397 \cdot \mathrm{X} 3+\mathrm{e}
$$

Tabel 8 menunjukkan bahwa pengaruh literasi keuangan pada kesejahteraan keuangan adalah signifikan dengan $p$-value $0,000(\leq 0,05)$, maka hipotesis $\mathrm{H}_{1}$ diterima. Nilai $T$ statistik tertinggi pada indikator variabel literasi keuangan yaitu pengetahuan produk keuangan sebesar 62,013. Pengaruh antara perencanaan keuangan pada kesejahteraan keuangan adalah signifikan dengan $p$-value $0,000(\leq$ 0,05), maka hipotesis $\mathrm{H}_{2}$ diterima. Nilai $\mathrm{T}$ statistik tertinggi pada indikator variabel perencanaan keuangan yaitu mengelola investasi sebesar 33,968. Pengaruh antara pendapatan pada kesejahteraan keuangan adalah signifikan dengan $p$-value $0,007(\leq 0,05)$, maka hipotesis $\mathrm{H}_{3}$ diterima. Nilai $\mathrm{T}$ statistik tertinggi pada indikator variabel pendapatan yaitu pendapatan utama sebesar 42,145 .

Tabel 8.

Hasil Uji Hipotesis

\begin{tabular}{lrrr}
\hline Variabel & $\begin{array}{c}\text { Nilai } \\
\text { sample estimate }\end{array}$ & $\begin{array}{c}\text { Original } \\
\text { T Statistik }\end{array}$ & \multicolumn{2}{c}{ Signifikansi } \\
\hline Literasi Keuangan & 0.473 & 7.526 & 0.000 \\
\hline Pengetahuan Produk Keuangan & & 62.013 & 0.000 \\
\hline Pengelolaan Keuangan & & 40.372 & 0.000 \\
\hline Kemampuan Keuangan & 38.712 & 0.000 \\
\hline Perencanaan Keuangan & 0.397 & 5.536 & 0.000 \\
\hline Mengelola Asuransi & & 26.293 & 0.000 \\
\hline Mengelola Investasi & & 33.968 & 0.000 \\
\hline Mengelola Pensiun & 0.158 & 29.398 & 0.000 \\
\hline Pendapatan & & 2.718 & 0.007 \\
\hline Pendapatan Utama & & 42.145 & 0.000 \\
\hline Pendapatan lain-lain & 34.317 & 0.000 \\
\hline Sumber Data primer dilah 2020 & &
\end{tabular}

Sumber: Data primer diolah, 2020

Pada penelitian ini hipotesis pertama adalah literasi keuangan berpengaruh terhadap kesejahteraan keuangan secara positif dan signifikan. Hasil analisis data menunjukkan bahwa literasi keuangan berpengaruh positif dan signifikan terhadap kesejahteraan keuangan pada guru-guru perempuan di Kota Denpasar. Hasil analisis data pada penelitian ini sejalan dengan hipotesis penelitian, artinya apabila terjadi peningkatan pada kualitas dan kemampuan literasi keuangan pada individu maka kesejahteraan keuangan individu tersebut mengalami peningkatan, begitu pula sebaliknya. Literasi keuangan mencakup pengetahuan, keterampilan dan keyakinan individu dalam mengatur keuangannya akan memengaruhi keputusan keuangan yang akan dibuat untuk mencapai kesejahteraan keuangan yang diharapkan.

Hasil pada penelitian ini mendukung konsep bahwa literasi keuangan berpengaruh terhadap kesejahteraan hidup seseorang utamanya kesejahteraan ekonomi. Pada teori kesejahteraan yang disampaikan Pigou (1929) peningkatan kesejahteraan ekonomi secara umum meningkatkan kesejahteraan secara total. Penelitian ini sejalan dengan Singh \& Kumar (2017), Haque \& Zulfiqar (2016), 
dan Kumar et al. (2019) yang menunjukkan bahwa literasi keuangan berpengaruh positif signifikan terhadap pemberdayaan dan kesejahteraan keuangan. Konsep literasi keuangan tercipta untuk mengetahui dan memanfaatkan produk-produk keuangan yang dapat membantu dan menunjang kebutuhan dalam pengelolaan keuangan. Literasi keuangan menjadi aspek yang penting apabila membahas terkait pengelolaan keuangan dan pencapaian kesejahteraan keuangan.

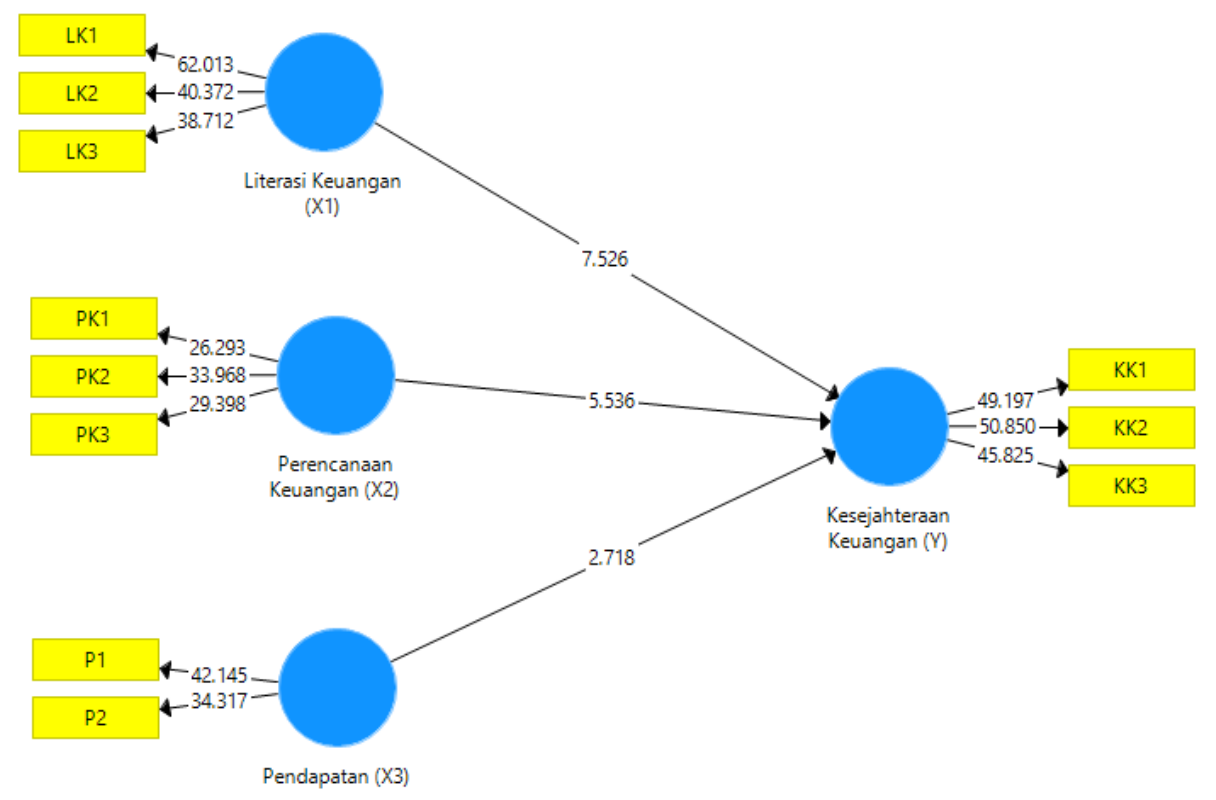

Gambar 2. Hasil Analisis PLS

Sumber: Hasil analisis data menggunakan SmartPLS 3

Berdasarkan hasil analisis literasi keuangan dengan indikator yang digunakan, indikator pengetahuan produk keuangan memiliki pengaruh yang terbesar. Hal tersebut menunjukkan bahwa pengetahuan individu terhadap produk-produk keuangan yang digunakan atau yang saat ini dikembangkan akan berpengaruh terhadap bagaimana individu tersebut mencapai kesejahteraannya. Pada dasarnya produk-produk keuangan diciptakan dengan tujuan untuk mempermudah hidup seseorang. Oleh karena itu pengetahuan yang baik tentang produk keuangan merupakan bagian dari literasi keuangan akan sangat membantu dalam memaksimalkan pemanfaatannya untuk mencapai kesejahteraan. Rendahnya literasi keuangan akan erat kaitannya dengan kemiskinan. Apabila terjadi krisis ekonomi, rendahnya literasi keuangan hanya akan memperparah dan memperpanjang krisis yang terjadi (Kovács \& Terták, 2019)

Pada penelitian ini hipotesis kedua menyatakan bahwa perencanaan keuangan berpengaruh terhadap kesejahteraan keuangan secara positif dan signifikan. Analisi data penelitian ini menghasilkan bahwa kesejahteraan keuangan berpengaruh positif dan signifikan terhadap kesejahteraan keuangan pada guru-guru perempuan di Kota Denpasar. Hasil analisis data sejalan dengan hipotesis penelitian, artinya apabila terjadi peningkatan pada kualitas dan kemampuan perencanaan keuangan yang dilakukan oleh individu maka 
kesejahteraan keuangan individu tersebut mengalami peningkatan, begitu pula sebaliknya. Perencanaan keuangan berkaitan dengan bagaimana individu mempersiapkan diri untuk menghadapi ketidakpastian di masa depan. Semakin baik perencanaan yang dibuat maka ketidakpastian yang seringkali merugikan dapat dihindari sehingga hal tersebut dapat membantu dalam mencapai kesejahteraan keuangan yang diharapkan.

Penelitian ini mendukung penelitian-penelitian sebelumnya oleh Brahmana \& Brahmana (2016), Yohanna \& Maya (2017), Fulda \& Lersch (2018) dan Kumar et al. (2019) bahwa perencanaan keuangan akan membantu dalam manajemen keuangan untuk mencapai kesejahteraan keuangan dan tujuan keuangan baik itu individu maupun badan. Hasil pada penelitian ini juga menunjukkan bahwa para guru-guru perempuan cenderung merencanakan keuangan untuk menghadapi ketidakpastian masa depan dengan mempersiapkan asuransi, dana pensiun, dan melakukan investasi.

Berdasarkan hasil analisis pada perencanaan keuangan, salah satu yang paling berpengaruh terhadap kesejahteraan keuangan adalah mengelola dana pensiun. Dana pensiun sudah menjadi salah satu bentuk perencanaan keuangan yang paling populer di masyarakat, karena manfaat adanya dana pensiun jelas terlihat dan dianggap membantu. Responden penelitian adalah guru-guru perempuan dengan tingkatan tertingginya adalah pada saat guru tersebut sudah berstatus pegawai negeri sipil (PNS) yang memberikan berbagai tunjangan dan jaminan salah satunya yaitu dana pensiun. Oleh karena itu pada responden guru mengelola pensiun menjadi salah satu perencanaan keuangan yang populer dan terdekat.

Hipotesis ketiga penelitian ini adalah pendapatan berpengaruh terhadap kesejahteraan keuangan secara positif dan signifikan. Hasil analisis data menunjukkan bahwa pendapatan berpengaruh positif dan signifikan terhadap kesejahteraan keuangan pada guru-guru perempuan di Kota Denpasar. Hasil analisis data penelitian sejalan dengan hipotesis penelitian yang sudah ditetapkan, artinya apabila terjadi peningkatan pendapatan pada individu maka kesejahteraan keuangan individu tersebut mengalami peningkatan, begitu pula juga apabila terjadi penurunan pendapatan maka kesejahteraan keuangan individu dapat mengalami penurunan.

Hasil penelitian ini mendukung penelitian yang dilakukan oleh Brüggen et al. (2017), Siregar \& Ritonga (2019), dan Zemtsov \& Osipova (2016) bahwa pendapatan berpengaruh terhadap kesejahteraan keuangan. Penelitian ini juga mendukung teori ekonomi kesejahteraan Pigou tentang teori kesejahteraan baik langsung maupun tidak langsung selalu dikaitkan dengan uang. Besarnya pendapatan sering menjadi tolok ukur kesejahteraan seseorang secara tidak formal. Berdasarkan hasil analisis data pada pendapatan, yang paling berpengaruh terhadap kesejahteraan keuangan adalah pendapatan utama atau pendapatan yang diperoleh oleh responden dari pekerjaan mereka sebagai guru. Berdasarkan hal tersebut menunjukkan bahwa kesejahteraan keuangan responden dicapai dengan pendapatan rutin yang diperoleh dari profesinya sebagai guru.

Implikasi dari hasil penelitian ini secara teoritis menambah referensi riset empiris tentang konsep literasi keuangan dan teori kesejahteraan. Terutama yang 
berkaitan dengan pengaruh literasi keuangan, perencanaan keuangan, dan pendapatan terhadap kesejahteraan keuangan. Individu yang membaca dapat mengetahui faktor yang berpengaruh dalam upaya mencapai kesejahteraan. Pemerintah atau Lembaga lain dapat menggunakan penelitian sebagai salah satu bahan rujukan untuk menambah informasi terkait pengukuran kesejahteraan pekerja. Dalam upaya memberikan tambahan informasi, penelitian ini diharapkan bermanfaat bagi masyarakat terkait bagaimana pentingnya literasi keuangan dapat membantu dalam upaya meningkatkan kesejahteraan. Serta, menjadi tambahan wacana dan literatur di bidang kesejahteraan dan literasi keuangan dalam fenomena yang terjadi pada masyarakat, sehingga dapat bermanfaat bagi peneliti selanjutnya yang sejenis dan berkaitan.

\section{SIMPULAN}

Melalui pengujian statistik dan pembahasan penelitian, maka dapat disimpulkan bahwa literasi keuangan berpengaruh secara positif dan signifikan terhadap kesejahteraan keuangan, artinya literasi keuangan yang mencakup pengetahuan, keterampilan dan keyakinan individu dalam mengatur keuangannya akan memengaruhi keputusan keuangan yang akan dibuat untuk meningkatkan kesejahteraan keuangan yang diharapkan. Perencanaan keuangan berpengaruh secara positif dan signifikan terhadap kesejahteraan keuangan, artinya perencanaan keuangan berkaitan dengan bagaimana individu mempersiapkan diri untuk menghadapi ketidakpastian di masa depan. Semakin baik perencanaan yang dibuat maka ketidakpastian yang seringkali merugikan dapat dihindari sehingga hal tersebut dapat membantu dalam mencapai kesejahteraan keuangan yang diharapkan. Pendapatan berpengaruh secara positif dan signifikan terhadap kesejahteraan keuangan, apabila terjadi peningkatan pendapatan pada individu maka kesejahteraan keuangan individu tersebut mengalami peningkatan, begitu pula juga apabila terjadi penurunan pendapatan maka kesejahteraan keuangan individu dapat mengalami penurunan.

Variabel yang digunakan dalam penelitian ini yaitu literasi keuangan, perencanaan keuangan, dan pendapatan untuk melihat pengaruhnya terhadap kesejahteraan keuangan pada guru-guru perempuan. Peneliti selanjutnya disarankan untuk menambah variabel gaya hidup dan persepsi risiko individu terhadap kesejahteraan. Kemudian, penelitian terbatas pada responden guru perempuan, maka disarankan peneliti selanjutnya dapat menggunakan subjek penelitian yang lebih luas dan beragam. Bagi pemerintah atau Otoritas Jasa Keuangan (OJK) yang khusus memperhatikan literasi dan inklusi keuangan untuk terus mengeluarkan kebijakan yang dapat membantu dalam meningkatkan literasi keuangan masyarakat luas mengingat betapa pentingnya pengetahuan dan kemampuan dalam mengelola keuangan.

\section{REFERENSI}

Adam, A. M., Frimpong, S., \& Boadu, M. O. (2017). Financial literacy and financial planning: Implication for financial well-being of retirees. Business and Economic

Horizons, $13(2)$, 224-236. 
https://doi.org/10.15208/beh.2017.17

Aulia, N., Yuliati, L. N., \& Muflikhati, I. (2019). Family's Financial Well -Being at Retiress Age: Financial Literacy, Retirement Planning, and Asset Ownership. Jurnal Ilmu Keluarga Dan Konsumen, 12(1), 38-51. https://doi.org/10.24156/jikk.2019.12.1.38

Badan Pusat Statistik. (2019). Indonesia 2019 Outlook. Laporan Perekonomian Indonesia 2019, 04(01), 2019-2020.

Boon, T. H., Yee, H. S., \& Ting, H. W. (2011). Financial literacy and personal financial planning in Klang Valley, Malaysia. International Journal of Economics and Management, 5(1), 149-168.

Brahmana, R. K., \& Brahmana, R. K. (2016). The Financial Planning and Financial Literacy of ex-Malaysia Indonesian Migrant Workers. Acta Oeconomica Pragensia, 24(5), 47-59. https://doi.org/10.18267/j.aop.557

Brown, S., \& Gray, D. (2016). Household finances and well-being in Australia: An empirical analysis of comparison effects. Journal of Economic Psychology, 53, 17-36. https://doi.org/10.1016/j.joep.2015.12.006

Brüggen, E. C., Hogreve, J., Holmlund, M., Kabadayi, S., \& Löfgren, M. (2017). Financial well-being: A conceptualization and research agenda. Journal of Business $\quad$ Research, 228-237. https://doi.org/10.1016/j.jbusres.2017.03.013

Chu, Z., Wang, Z., Xiao, J. J., \& Zhang, W. (2017). Financial Literacy, Portfolio Choice and Financial Well-Being. Social Indicators Research, 132(2), 799820. https://doi.org/10.1007/s11205-016-1309-2

Consumer Financial Protection Bureau. (2015). Measuring financial well-being: A guide to using the CFPB Financial Well-Being Scale. Https://Www.Consumerfinance.Gov/, December, 31.

Fulda, B. E., \& Lersch, P. M. (2018). Planning Until Death Do Us Part: Partnership Status and Financial Planning Horizon. Journal of Marriage and Family, 80(2), 409-425. https://doi.org/10.1111/jomf.12458

Ghozali, Imam, Hengky Latan. (2015). Konsep, Teknik, Aplikasi Menggunakan Smart PLS 3.0 Untuk Penelitian Empiris. Semarang: Bp Undip.

Hair, J.F., W.C. Black, B.J. Babin, R.E. Anderson,R.L.Tatham, (2006). Multivariate Data Analysis ( $6^{\text {th }}$ ed). New Jersey: Prentice-Hall.

Haque, Abdul; Zulfiqar, M. (2016). Women's Economic Empowerment through Financial Literacy, Financial Attitude and Financial Wellbeing. International Journal of Business and Social Science, 7(3), 78-88.

Indrayani, S. (2018). Pengaruh Pendapatan, Pengetahuan, Dan Pengalaman 
Keuangan Terhadap Perilaku Perencanaan Investasi Keluarga. Journal of Chemical Information and Modeling, 53(9), 1689-1699. https://doi.org/10.1017/CBO9781107415324.004

Joo, S. H., \& Grable, J. E. (2004). An exploratory framework of the determinants of financial satisfaction. Journal of Family and Economic Issues, 25(1), 2550. https://doi.org/10.1023/B:JEEI.0000016722.37994.9f

Joseph, J., \& McGregor, J. A. (2020). Wellbeing, Resilience, and Sustainability: The New Trinity of Governance.

Kay, J. (2017). The Basics of Basic Income. Intereconomics, 52(2), 69-74. https://doi.org/10.1007/s10272-017-0648-9

Kementrian Pemberdayaan Perempuan dan Perlindungan anak. (2019). Pr o f i 1 e r e mp u ON. Profil Perempuan Indonesia.

Kementerian Pendidikan dan Kebudayaan. (2020). Data Guru Semester Ganjil 2020/2021. Retrieved from https://kemendikbud.go.id/

Kovács, L., \& Terták, E. (2019). Financial Literacy: Theory and Evidence. 150. http://www.bankszovetseg.hu/Public/publikacio/Financial literacy.pdf

Kumar, S., Tomar, S., \& Verma, D. (2019). Women's financial planning for retirement: Systematic literature review and future research agenda. International Journal of Bank Marketing, 37(1), 120-141. https://doi.org/10.1108/IJBM-08-2017-0165

Lin, C., Hsiao, Y. J., \& Yeh, C. Y. (2017). Financial literacy, financial advisors, and information sources on demand for life insurance. Pacific Basin Finance Journal, 43, 218-237. https://doi.org/10.1016/j.pacfin.2017.04.002

Mahdzan, N. S., Zainudin, R., Sukor, M. E. A., Zainir, F., \& Wan Ahmad, W. M. (2019). Determinants of Subjective Financial Well-Being Across Three Different Household Income Groups in Malaysia. Social Indicators Research, 146(3), 699-726. https://doi.org/10.1007/s11205-019-02138-4

OECD. (2016). PISA 2015 Assessment and Analytical Framework: Science, Reading, Mathematic and Financial Literacy. Paris: PISA.OECD Publishing.

OJK. (2017). Strategi Nasional Literasi Keuangan Indonesia (Revisit 2017). Otoritas Jasa Keuangan, 1-99.

Palameta, B., Nguyen, C., Hui, T. S., \& Gyarmati, D. (2016). The Link between Financial Confidence and Financial Outcomes among Working-Aged Canadians for the Financial Consumer Agency of Canada. The Social Research and Demonstration Corporation (SRDC), May, 1-63.

Pigou, A. C. (1929). The Economis of Welfare. 
Purwidianti, W., \& Mudjiyanti, R. (2016). Analisis Pengaruh Pengalaman Keuangan Dan Tingkat Pendapatan Terhadap Perilaku Keuangan Keluarga Di Kecamatan Purwokerto Timur. Benefit: Jurnal Manajemen Dan Bisnis, 1(2), 141. https://doi.org/10.23917/benefit.v1i2.3257

Rustia, H. N. (2012). Mengukur kesejahteraan. Jurnal Ekonomi Dan Kebijakan Publik, 225-232.

Sekaran, U. (2006). Research Method for Business. John Wiley \& Sons, Inc, 160.

Singh, C., \& Kumar, R. (2017). Study of Women's Financial Literacy - A Case of BHU. Pacific Business Review International, 10(4), 128-136.

Siregar, N. A., \& Ritonga, Z. (2019). Analisis Tingkat Pendidikan Dan Tingkat Pendapatan Terhadap Kesejahteraan Sosial Di Kabupaten Labuhanbatu. Jurnal Informatika, 6(1), 1-10. https://doi.org/10.36987/informatika.v6i1.736

Sugiyono. (2017). Metode Penelitian Kuantitatif, Kualitatif, dan R\&D. Bandung: Alfabeta.

SNLKI. (2019). Siaran Pers Survei OJK 2019: Indeks Literasi Dan Inklusi Keuangan Meningkat. Sp 58/Dhms/Ojk/Xi/2019, November, 1.

Tarigan, L. (2017). Contoh Perencanaan dan Pengelolaan Keuangan Pribadi atau Rumah Tangga dalam Meningkatkan Kesejahteraan Examples of Personal and Household Financial Planning and Management in Improving Prosperity. 9816(2), 2540-9220.

Yohanna, L., \& Maya, S. (2018). Upaya Peningkatan Kesejahteraan Keluarga Melalui Pelatihan Manajemen Keuangan Keluarga. Proceeding of Community Development, l(October), 25. https://doi.org/10.30874/comdev.2017.4

Yushita, A. N. (2017). Pentingnya Literasi Keuangan Bagi Pengelolaan Keuangan Pribadi. Nominal, Barometer Riset Akuntansi Dan Manajemen, 6(1). https://doi.org/10.21831/nominal.v6i1.14330

Zemtsov, A. A., \& Osipova, T. Y. (2016). Financial Wellbeing as a Type of Human Wellbeing: Theoretical Review. 385-392. https://doi.org/10.15405/epsbs.2016.02.49 